\title{
Semantic Approach to Verbal Humor Across Cultural Barriers in Comic TV Shows
}

\author{
Salma M. Kamel \\ Department of English, Faculty of Al-Alsun (Languages), Minia University \\ salmamsk@mu.edu.eg
}

Received: August 19, 2020 Accepted: October 8, 2020 Published: October 26, 2020

\begin{abstract}
This research paper aims to approach verbal techniques of humor creation in comic TV shows. Comedians usually play with words and expressions to create various readings. The various readings are the basis of humorous incongruity. Following Raskin's (1985) Semantic Script Theory of Humour (SSTH), the research paper's approach is semantic, aiming to analyze linguistically how comedians joke verbally in front of an audience in comic TV shows. The research paper also sheds light on whether or not semantic sense relations, especially homonymy and polysemy, are the basic techniques of verbal incongruity. Besides, figurative language and parody are approached to show to what extent they are creating elements of humor in comic TV shows. Cultural barriers are put into consideration throughout the analysis via the role of cultural literacy between the comedians and the audience. Consequently, the contribution of the research paper is the semantic approach via a qualitative framework to analyze techniques of verbal humor in addition to the role of culture in comic TV shows.
\end{abstract}

Keywords: humor, comic TV shows, semantics, figurative language, culture

\section{Introduction}

Humor is part and parcel of life and thought. Whenever an unexpected thing is said or done, many people laugh. As humor is socially bound, based on Ross (1998, pp. 1-2), not all people are ready for laughter. In other words, humor depends on the extent of people's solidarity and the 
situation in which people might laugh or not. Some situations tend to be too serious to cause laughter while other situations do not. For instance, people often laugh in a serious or an embarrassing situation (e.g. slipping over a banana peel, a mistake in recognizing other people we meet by chance, etc.). Some jokes tend to cause laughter in certain contexts but they do not in other contexts Ross (1998, pp. 1-2). As long as humor relies on social relationships between people, it is bound to rely on cultural differences. Since people all over the world watch contemporary comic TV shows, inquiries can be made whether or not verbal humor can be the same in every country's comic TV shows, and whether or not the comedians utilize language semantically across cultural barriers in a specific way to create verbal humor. Hence, the main focus is to approach the techniques of verbal humor creation in Arabic and English comic TV shows. The previously mentioned problem of the research paper raises the following questions:

1. To what extent are techniques of verbal humor variant in Arabic and English comic TV shows?

2. Does verbal humor creation depends on comedians themselves?

3. How far is semantics sufficient to analyze verbal humor creation?

4. How do cultural differences influence verbal humor creation?

More often than not, comedians deliver humor verbally employing wordplay and puns. Wordplay is a technique in which the meaning of words deviates funnily (Literary Terms, n.d.). A pun is considered as a subcategory of wordplay (also called 'paronomasia') that suggests different meanings from the original one of a word. This is also known as the double meaning technique in humor (Encyclopedia Britannica, 2013). An example of puns is found in the joke said by the American comedian Steven Wright: 'I have an existential map. It has 'You are here' written all over it" (Ross, 1998, p.3). The pun is created by the double meaning of the word 'existential' which means both location and the existence of something or somebody. It is the punch line "It has 'You are here' written all over it" which enhances the pun and thus creates a humorous incongruity.

Another example of pun is in this Egyptian Arabic joke by the Egyptian 
comedian Hamada Sultan:

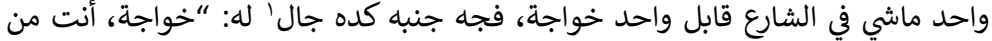

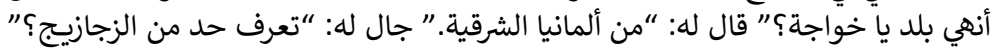

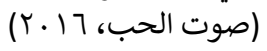

A pedestrian met a foreigner. He stood next to the foreigner and told him: "Mister, where are you from?" The foreigner answered: "From Eastern Germany." The pedestrian told him: "Do you know someone from ElZagazig?"

The pun here is reflected by the word 'الشرقية' (El-Sharkeya). It refers to Eastern Germany (the direction of the east) as shown by the foreigner's nationality. However, it has the same pronunciation of 'الشرقية' (ElSharkeya) governorate in Egypt where 'الزقازيق' (El-Zaqaziq) is located. So, the pun is shown in the punch line: The foreigner meant Eastern Germany while the pedestrian misunderstood it as El-Sharkeya. According to Ross, the punch line is the final line or part of a joke which does not have the expected consequence of the joke $(1998$, p. 8). The role of the unexpectedness in humor is taken into consideration in the study

\section{Contribution of the Research}

This study seeks to analyze semantically techniques of creating verbal humor in comic TV shows. Such TV shows present new aspects of comedy which this study tackles. The study investigates how humor is created semantically with the help of denotation, connotation, collocation, and figurative language. Also, it sheds light on other techniques such as verbal parody and extended imagination. Another target of the study is to analyze the role of culture in discerning verbal humor in comic TV shows.

\section{Literature Review}

The semantic approach to verbal humor was previously attempted. The most significant semantic approach is proposed by Victor Raskin in his book Semantic Mechanisms of Humour. It is essential for humor research

\footnotetext{
${ }^{1}$ In order to clarify the pronunciation of the letter ' 3 ' in the Upper Egyptian accent, IPA (International Phonetic Alphabet) is used throughout the paper. The verb "جال" (said) /ga:1/ is an example of the Upper Egyptian accent. The verb is 'قال' /qa:1/ in Standard Arabic. The first letter of the verb ' accent. The same applies to "الزقازيق /PIz-zaqa:zi:q/. Thus, it is pronounced as /?I'zægəzi:g/.
} 
paper, especially on the semantic-cognitive level. Raskin's Semantic Script Theory of Humour (SSTH) provides a methodology of analyzing ambiguity in jokes with a high focus on incongruity. That theory was developed to deal with unexpectedness in jokes. The theory is helpful to analyze incongruity in jokes semantically and cognitively. Based on Raskin, a text is considered as humorous if it is compatible with both of the following conditions:

i) The text is compatible, fully or in part, with two different scripts

ii) The two scripts with which the text is compatible are opposite (...).

The two scripts with which some text is compatible are said to overlap fully or in part on this text. (Raskin 1985, p. 99)

A script is defined as "an organized chunk of information about something (in the broadest sense). It is a cognitive structure internalized by the speaker which provides the speaker with information on how things are done, organized, etc." (Attardo, 1994, p. 198). For instance, the previously mentioned Sultan's joke is an example of a clear overlapping between two scripts. The joke contains two overlapping scripts about 'الشرقية' (El-Sharkeya). The first script is the normally expected one about 'ألمانيا الشرقية' (Eastern Germany). However, the other overlapping script of El-Sharkeya is indicated by the word 'الزجازيج' (El-Zagazig). Such a play between an expected meaning or script and an unexpected meaning or script is known as incongruity in humor. Attardo (1994, p. 48) mentions Morreall's quotation (1987, p. 47) which is about the philosopher Kant's definition of humor. "Laughter", in Kant's words, “is an affection arising from sudden transformation of a strained expectation into nothing" (1790, p. 177). Kant's definition confirms his view that incongruity is based on the relationship between the expected and the unexpected in ideas.

There is further literature which proposed semantic approaches to verbal humor. For example, there is a book entitled Linguistic Theories of Humour by Attardo (1994). The book is about humor and various logical, philosophical, semantic, syntactic, and pragmatic theories. It focuses on the analysis of puns. Another book by Attardo (2001) is entitled Humourous Texts: A Semantic and Pragmatic Analysis. It tends to be almost similar to Linguistic Theories of Humour. The only new topics 
that mark this book are those related to the structure of jokes, narrative texts and irony. Another influential book is The Language of Humour by Ross (1998). She analyses the language of humor by utilizing various morphological, syntactic, semantic, and pragmatic theories with exemplification. She also deals with literature, spoken humor like those of television and radio, and stand-up comedy. There is also a Ph.D. thesis by Carrell (1993) entitled Audience/Community, Situation, and Language: A Linguistic/Rhetorical Theory of Verbal Humour. Carrell (1993) approaches verbal humor linguistically and rhetorically in addition to explaining most of the theories dealing with comedy semantically, pragmatically, contextually, and rhetorically. However, her findings are confirming the vital role of the audience and situation along with the joke teller and joke text. She also gives examples of verbal jokes in her analysis. Therefore, her thesis is mainly an attempt to prove how the audience, joke teller, situation, and purpose of the joke form a whole entity which leads to humor in verbal jokes.

This study might contribute to humor research for the following reasons. Linguistically speaking, the literature mentioned above focuses majorly on verbal humor concerning phonetics, morphology, syntax, semantics, cognition, and pragmatics. On the other hand, this study proposes a focused semantic approach to verbal humor putting cultural factors into consideration. Semantically speaking, Raskin's SSTH approaches humor while almost ignoring a more profound account of denotation, connotation, and collocation in semantic shift. SSTH also deals with pragmatic non-bona-fide communication. Semantic shift leads to humorous effects accomplished by puns or wordplay. This is the major focus of the research paper. Thus, the paper might add a paucity of contribution to humor research paper via a profound, semantic analysis of verbal humor in comic TV shows across cultural barriers.

\section{Method and Procedure}

The research paper's methodology is semantic, aiming to tackle incongruous messages of verbal humor via wordplay, puns, and figurative language. According to Palmer, "semantics is the technical term used to refer to the study of meaning" (1981, p. 1). The relationship 
between the meaning of words is shown in sense relations because "sense relates to the complex system of relationships that hold between the linguistic elements themselves (mostly the words); it is concerned only with intralinguistic relations" (Palmer, 1981, p. 29). Homonymy and polysemy are the common two sense relations that are behind many instances of wordplay and puns. They cause semantic ambiguity by confusion in meaning. That is to say, ambiguity happens semantically when a word means more than one sense. Homonymy means different words that have the same form while they have different meanings (Simpson, 1997, p. 69). For instance, the word 'bank' has two meanings in this sentence "They went to the bank yesterday". 'Bank' is probably of a Scandinavian origin meaning a shore of a river. The second meaning of the same word is of a French origin meaning a financial institution. Hence, 'bank' means either a 'financial institution' or a 'river shore' (Simpson, 1997, p. 69)

On the other hand, polysemy is a sense relation which indicates that "the same word may have a different set of meanings" (Palmer, 1981, p. 100). For example, the word 'flights' in the sentence "They had several flights" is polysemic. 'Flight' means: "passing through the air", "power of flying", "air journey", "unit of the Air Force", "volley", "digression", and "series of steps" (Palmer, 1981, p. 100). The various senses of the same word 'flight' make the sentence have various meanings.

An example in Arabic is the verb 'أصبح' in the sentence 'أصبح الولد نشيطاً'. The verb has two meanings. First, it refers to 'become' or a change in condition; that is to say, the boy used to be lazy in the past, but nowadays he is active. So, the sentence can mean 'The boy became active'. On the other hand, the verb 'أصبح' (derived from 'الصباح' which means 'morning') means 'woke up in the morning'. So, the sentence can mean 'The boy woke up actively in the morning'. The study then tackles such verbal techniques in data from comic TV shows.

The linguistic data of this study are samples from contemporary comic TV shows in Arabic and English. The data is haphazardly selected based on the focus of the research paper. Data of Arabic comic TV shows are from البرنامج) (The Program) presented by the Egyptian comedian Bassem 
Youssef, بني آدم شو (A Human Being's Show. The title shows a pun in 'بني 'أدم 'meaning 'human being' and alluding to 'Adam' as a proper noun.) presented by the Egyptian actor and comedian Ahmad Adam, مأسعد الله (Good Evening) presented by the Egyptian satirist Akram Hosni who plays the role of Abo Hafiza, and مفيش مشكلة خالص (No Problem at All) presented by the Egyptian actor Muhammad Sobhi. On the other hand, data from English comic TV shows are from The Daily Show presented by the American comedian Jon Stewart and currently, by the South African comedian Trevor Noah, Last Week Tonight with John Oliver presented by the English-American comedian John Oliver, Late Night with Conan O'Brien presented by the American comedian Conan O'Brien, and Live at the Apollo presented by various English and American stand-up comedians. The approach of the study is semantic within a qualitative framework in order to foreground techniques of verbal humor in comic TV shows. That is to say, every section is entitled by the verbal humor technique. A cultural approach succeeds in the qualitative analysis to find out the cultural elements which make humor culturally-specific. The aim of the cultural approach is to foreground the role of cultural differences and their effect on verbal humor.

\section{Cultural Barriers in Humor}

Cultural barriers play an important role in discerning humor techniques in comic TV shows. Tsakona (2018, p. 88) quotes a definition of cultural literacy in her article "Intertextuality and Cultural Literacy in Contemporary Political Jokes" published in Arie Sover's The Languages of Humor: Verbal, Visual, and Physical Humor. She mentions Hirsch's definition as follows: "Cultural literacy implies ... shared knowledge about ourselves, our history and our world, our laws, our political, economic, and social arrangements, our classical texts from a great many domains including TV, the movies, and literature" (1980, p. 45). Cultural literacy is the key element of overcoming the cultural barriers against the success of humor. If comedians and their audience were not aware of their own culture and what surrounds them, humor would be a failure. The same applies to discerning humor in foreign comic TV shows. If the audience were not aware of the foreign country's culture, discerning humor in such a foreign comic TV show would not succeed. In other 
words, cultural literacy is not necessarily national. It can be national or international to overcome cultural barriers. Therefore, the following analysis clarifies cultural literacy and its role.

\section{Analysis and Exemplification}

\subsection{Collocational clash}

Toolan defines collocation as "the far-greater-than-chance tendency of particular words to co-occur (adjacently or within a few words of one another). These co-occurrence tendencies have text-constructional and semantic implications" (2009, p. 19). For instance, the phrase 'a bold man' collocates together while 'a pretty man' does not. The word 'bold' carries lexical constituents more suitable for men: [+male] and [cowardly]. However, the word 'pretty' has lexical constituents more suitable for describing women: [+female] and [-male]. Such an incompatibility causes a collocational clash which creates incongruity and surprise in humor. Collocational clashes can be used to create incongruity which leads to the humor.

An example of collocational clash is found in this section from Sobhi's مغيش مشكلة خالص (No Problem at All). He wore a white suit with an apparent black spot on it. He was asking a few among the audience about their honest opinion on the suit as follows:

$$
\begin{aligned}
& \text { (1) محمد صبحي: “أوعي تجامليني! قولي الحقيقة، إيه اللي شايفاه في بدلتي؟” ((يعطي فتاة من }
\end{aligned}
$$

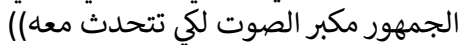

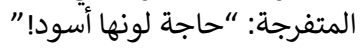

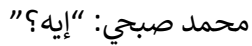

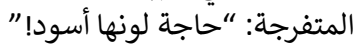

$$
\begin{aligned}
& \text { محمد صبحي: “((في ذهول)) واحدة شافت أسود! ((يضحك الجمهور)) إيه؟ - إيه }
\end{aligned}
$$

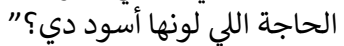

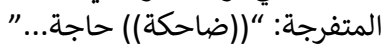

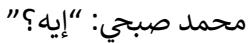

$$
\begin{aligned}
& \text { المتفرجة: "تراب!" }
\end{aligned}
$$

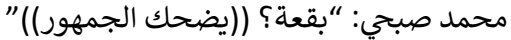

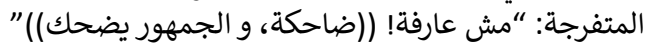

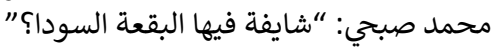

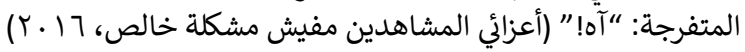

Muhammad Sobhi: "Don't compliment me! Tell me the truth: What do you see in my suit?" ((He gives a girl among the audience the microphone to talk to him.))

The girl: "A black thing!" 
Muhammad Sobhi: "What?"

The girl: "A black thing!"

Muhammad Sobhi: ((in amazement)) "Someone has seen black!" ((The audience laughs)) What - What's that black thing?"

The girl: ((laughing)) "Something..."

Muhammad Sobhi: "What?"

The girl: "Dust!"

Muhammad Sobhi: "A spot?" ((The audience laughs.))

The girl: "I don't know!" ((She laughs, and so does the audience.))

Muhammad Sobhi: "Do you see the black spot in it?"

The girl: "Yes!"

Incongruity results from the difference between the color of the suit (white) and the color of the spot on the suit (black). The collocational clash between 'سودا' (black) and 'بيضا' (white) is shown as follows:

\begin{tabular}{cc} 
[-light] & \multicolumn{1}{c}{ [+light] } \\
[+dark] & [-dark]
\end{tabular}

Sobhi's white suit forms a collocational clash with the black spot on it. Based on Raskin's SSTH theory (1985, p. 99), the clashing readings are the incongruous scripts. Sobhi's comment in amazement ' واحدة شافت 'أسود (Someone has seen black) emphasizes such a collocational clash between the lexical constituents of 'أسود' 'أبيض', causing incongruity and humor.

Another instance of collocational clash is provided by Stewart in this section from The Daily Show, Season 4, Episode 91. The episode was broadcast in January 2000. Stewart deals with an annual meeting of the World Economic Forum²:

(2) Stewart: "Microsoft Chairman Bill Gates discussed the future - of the telephone."

A scene from the annual meeting featuring Bill Gates talking: "When you go on website, you will be able to talk, you should navigate through that website and look at products you're interested in."

Stewart: "And when you just feel like talking, you know, really talking ((The audience laughs)), a digital clock will loudly count down these seconds you should be working! ((The audience laughs)) Gates and AOL Chairman Steve Case described the future when television, the internet, and mobile phone will

2 The forum is usually held in Davos, Switzerland, to discuss various issues with people, public figures, or heads of large companies worldwide (The World Economic Forum, n.d.). 
merge together - and fight crime. (A shot of the famous animated robot Voltron is shown, and the audience laughs and applauds). (The Daily Show, 2000)

Stewart satirically comments on Bill Gates' words "When you go on website, you will be able to talk, you should navigate through that website and look at products you're interested in". He imagines humorously when people start using such a new technology of communication Gates suggests, they will use it for talking frequently. Thus, they will waste time, and this is why he says "a digital clock will loudly count down these seconds you should be working". Stewart creates two contradictory readings by means of the lexical constituents of the two words 'talking' and 'working'. These readings can be represented by the lexical constituents of the two words:

Talking

[+time wasting]

[+trivial]

[-serious]
Working

[-time wasting]

[-trivial]

[+serious]

Stewart wants to convey that such a new means of communication may be a waste of time. Bill Gates talks about the benefits of this new means of communication while Stewart talks about its negative side as a waste of time, drawing people's attention away from their work. That is to say, the way Gates deals with the new technology and the way Stewart does are contradictory. The collocational clash triggers the contradictory readings which lead to humor.

Another role of collocational clash in humor is seen in this section from Live at the Apollo, Season 4, Episode 6. The guest is the English comedian Russell Howard, and the episode was broadcast on January 16, 2009:

(3) I've been travelling all over the places, and have been got on tour, right? I've seen some really weird things, right? Obviously the sandwich shop the other day, you ever see a sign that really annoys you. ((Raising his right hand parallel to the following words)) There's this big sign that said "Hey! Why not try a guilt-free wrap?" Whoa! ((Astonished, drawing his face backward)) Don't make sandwiches evil, how ridiculous is that? ((The audience laughs)) Sandwiches are lovely! The bacon sandwich is one of the greatest things in the world! ((moving his right hand for emphasis)) It tastes lovely and conceptually, 
it's a wonderful thing. A bacon sandwich is essentially bread giving a dead pig a cuddle ((opening his arms as if he hugs someone)) ((The audience laughs)), it's a lovely thing! (Arse Raptor, 2009)

Howard talks about his touring and an advertisement which drew his attention during his travel. He criticizes the advertisement that he came across while he was on tour once before. The statement of the advertisement 'Why not try a guilt-free wrap?' embodies a collocational clash as follows:

$\begin{array}{ll}\text { Guilt-free } & \text { Sandwich } \\ \text { [-negative] } & \text { [+negative] } \\ \text { [-calories] } & \text { [+calories] } \\ \text { [-food] } & {[+ \text { food }]}\end{array}$

The semantic constituents of 'guilt-free' and 'sandwich' are contradictory. The advertisement promoted a sandwich with low calories so that people, especially those going on diet, can enjoy it without worry. However, Howard utilizes this collocational clash for humor and starts to praise sandwiches with high calories by saying "Sandwiches are lovely! The bacon sandwich is one of the greatest things in the world! It tastes lovely and conceptually, it's a wonderful thing". Guilt-free sandwiches contradict sandwiches with high calories. Howard uses this contradiction to create verbal humor.

\subsection{Connotational shift}

A connotation is "used variously to refer to differences in meaning that cannot be reduced to differences in denotation" (Oxford Concise Dictionary of Linguistics, 2014, p. 74). The connotation is different from denotation which means "the relation between a lexical unit and the objects etc. it is used to refer to" (Oxford Concise Dictionary of Linguistics, 2014, p. 98). For instance, 'professional' has a denotation of 'clever' but with other various connotations of 'high skill', 'efficiency at work', and 'paid work'. Connotations of words may shift according to various contexts. Comedians can shift connotations of words to create humor.

In Episode 2, Season 2 of Last Week Tonight with John Oliver, changing the connotations of the word 'lighter' enables an incongruous impact to 
make the audience laugh. Such an instance of connotational shift is in this section:

(4) A video from a reporter while the reporter says: "This is the entrance to a school and, come with me, just a few steps away from the entrance, there is this kiosk that is sponsored by Marlboro Lights, and at this kiosk, a student can come and buy an individual cigarette, they're only a dime a piece, and they even have a lighter on a string."

John: "Yeah, wha - of course the lighter is on a string! What kind of irresponsible cigarette vendor outside the school? ((The audience laughs)) Would they let a child walk away ((moving two fingers of his right hand as if he represents the two feet of a person who walks)) with a lighter ((raising his hand as if he holds a lighter))? They're dangerous!!! ((The audience laughs)) Think about it! ((The audience applauds)) Just think about that! ((The audience laughs))" (Last Week Tonight, 2015)

With the help of another surrounding lexicon, a connotation can be shifted to create humor. Lexicon means "the vocabulary of a language" and all the information about a language's meaningful units (Murphy \& Koskela, 2010, p. 95). The following illustration shows the connotations of the word 'lighter' (Illustration is mine):

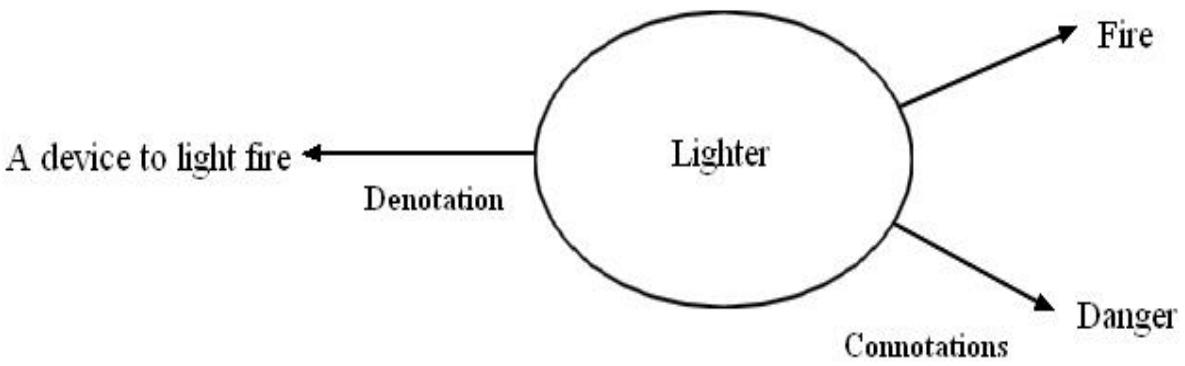

Figure 1. The connotations of the word 'lighter'

The sense of the word 'child' causes the connotation of the word 'lighter' to be changed from 'fire' into 'danger'. When Oliver says "What kind of irresponsible cigarette vendor outside the school? Would they let a child walk away with a lighter? They're dangerous!!!”, he creates incongruity by referring to a different context from the original one about smoking. There is another lexicon that helps to create such a different context: 'irresponsible' and 'dangerous'. Instead of enhancing the original issue about smoking and tobacco being sold to children, Oliver makes the 
audience laugh as he shifts the connotation of the word lighter from 'fire' into 'danger' and also the context from children who smoke into the danger of holding lighters.

\subsection{Verbal simile}

A simile is a "figure of speech involving a comparison between two, unlike entities. In the simile, unlike the metaphor, the resemblance is explicitly indicated by the words 'like' or 'as"' (Encyclopedia Britannica, 1998). For example, the sentence 'Ann sings like a nightingale' has a simile. Verbal simile can be likened to the following equation:

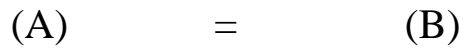

'like' or 'as'

The simile shows that Ann's voice is as beautiful as a nightingale's when she sings. On applying the equation on the simile, (A) is 'Ann', and (B) is 'a nightingale': Ann = A nightingale. Such an improvised equation shows how verbal simile works.

An instance of verbal simile happens when Adam talks about the role of nanotechnology humorously in this section from Bani Adam Show, Season 1. The episode was broadcast on December 10, 2009:

$$
\begin{aligned}
& \text { (5) آدم: “و قدروا العلماء النانو تكنولوجي إنهم يخترعوا - يعني الحاجات دي أصبحت يعني شبه إنداء }
\end{aligned}
$$

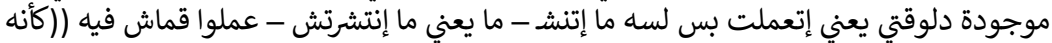

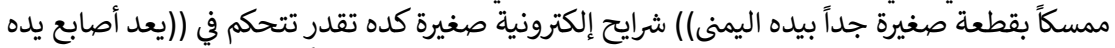

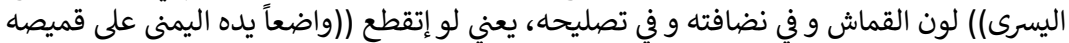

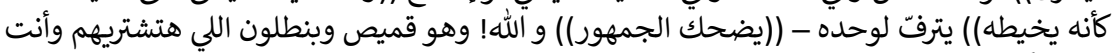

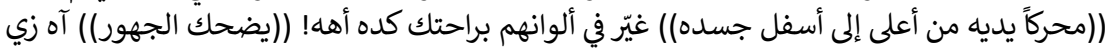

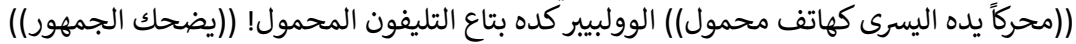

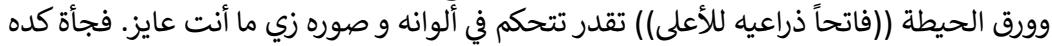

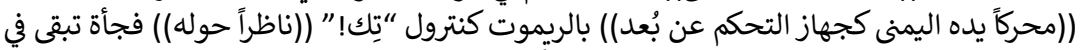

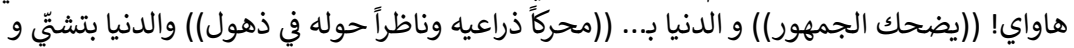

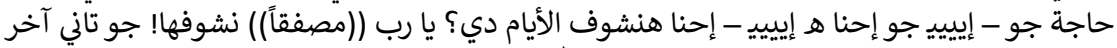

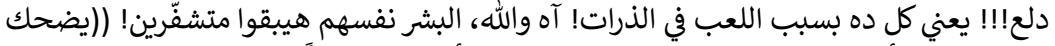

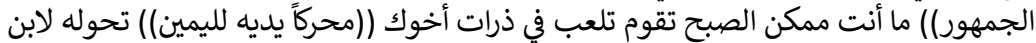

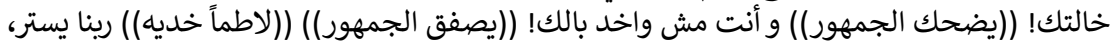

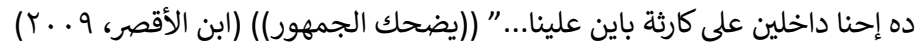

Adam: "Nanotechnology scientists managed to invent - I mean, these things have almost become available nowadays, you know, they have been made but haven't been promo - I mean not promoted - have made cloth which has ((as if he holds a tiny item by his right hand)) small electronic slices that make you 
control ((counting by his left hand)) the color, the cleanliness, and mending the cloth. If it is cut ((putting his right hand on his shirt as if he sews it)), it sews itself - ((The audience laughs)) really! They're just a shirt and pants that you'll buy, and you ((moving his hands over his body from top to bottom)) change their colors as you like! ((The audience laughs)) Yeah, like ((moving his left hand like a mobile phone)) mobile wallpaper! ((The audience laughs)) You can control the colors and the pictures of the wallpaper ((opening his hand upwards)) as you like. Suddenly ((moving his right hand like a remote control)) with a remote control "Tick!" ((looking around)) all of a sudden you'll be in Hawaii! ((The audience laughs)) It feels like ... ((moving his arms while looking around in amazement)) It feels like winter and the weather is Wooooow it's woooow - will we witness such days? I hope ((clapping his hands)) we will. Such another fantastic weather!!! All of that because of modifying atoms! Oh really, human beings themselves will be scrambled! ((The audience laughs)) You can modify the atoms of your brother in the morning ((moving his hands to the right)) so that you can convert him into your cousin! ((The audience laughs)) While you're not aware of that! ((The audience applauds)) ((beating his cheeks)) Oh no, we're on the verge of a disaster, I think ..." ((The audience laughs))

Adam deals with nanotechnology ${ }^{3}$ in this section from the show.

Considering the verbal simile, Adam likens the ability to change the colors of clothes to the ability to change mobile wallpapers when he says:

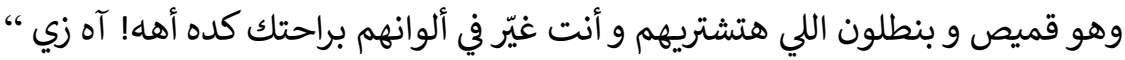
(They're just a shirt and pants that you'll buy, and you change their colors as you like! Yeah, like mobile wallpaper!). The keyword of the simile in Egyptian colloquial is 'زي' which means 'like'. The word 'زي' links changing the colors of shirt and pants to changing mobile wallpapers. In Egyptian colloquial, verbal simile can be as follows:

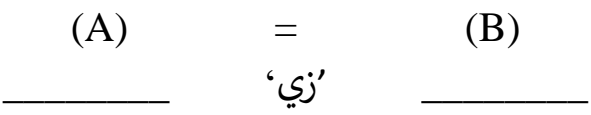

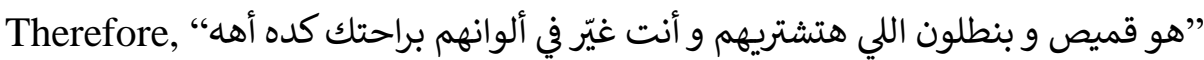

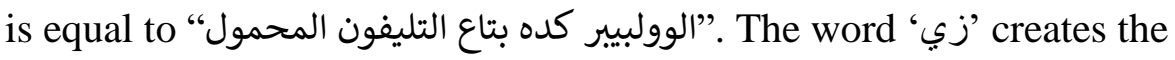
link of similarity between both ways of changing colors, and the verbal simile results.

Another verbal simile is used by Oliver in Episode 11, Season 3 of Last Week Tonight with John Oliver. He satirizes the inaccurate results of

\footnotetext{
${ }^{3}$ Nanotechnology is the "manipulation and manufacture of materials and devices on the scale of atoms or small groups of atoms" (Encyclopedia Britannica, 2005).
} 
some scientific studies as follows:

(6) A scene from Fox News is featured in which a presenter talks about a result of a specific new study.

The presenter: "A new study showing that drinking a glass of red wine is just as good as spending an hour at the gym." ((The audience laughs))

Oliver: "What?! ((The audience laughs and applauds)) Tha - That last one? No! No! No! No! N - That last one doesn't even sound like science! It's more like something your sassy aunt would wear on a t-shirt!" ((The audience laughs)) (Last Week Tonight, 2016)

Oliver disbelieves the result of such a study as mentioned above. He likens its result to a sassy aunt wearing a t-shirt with the words: "A glass of red wine is just as good as spending an hour at the gym." In other words, the result of the study is likened incongruously to words written on a t-shirt. The equation of the verbal simile can be applied as follows:
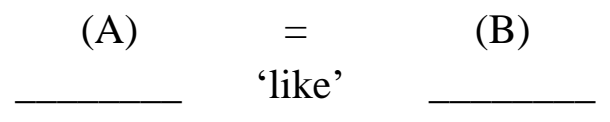

'It's (a glass of red wine is just as good as spending an hour at the gym)' $=$ 'something your sassy aunt would wear on a t-shirt'. The function of the simile is sarcasm. Oliver sarcastically belittles the inaccurate results of scientific studies likening them to fancy phrases on t-shirts. The simile enhances the triviality of such inaccurate results.

\subsection{Verbal metaphor}

Another technique used to create humor in comic TV shows is the verbal metaphor. A metaphor is a figure of speech which "consists of a 'literal' primary subject (or 'tenor') expressed in terms of a 'figurative' secondary subject (or 'vehicle')" (Richards, 1932, p. 96). Chandler (2007, p. 127) exemplifies a metaphor by mentioning a famous quote said by the German poet Heinrich Heine: "'Experience is a good school, but the fees are high'. In this case, the primary subject of experience is expressed in terms of the secondary subject of school." The tenor and the vehicle of metaphors are the source of incongruity and contradictory readings.

An example of a metaphor in comic TV shows is provided in this section from Episode 21, Season 2 of Last Week Tonight with John Oliver.

Oliver satirizes people who waste food in the USA as follows: 
(7) (A scene from another TV show hosting Dana Gunders, a staff member at Food and Agriculture Program at NRDC, is featured.)

Gunders: "In our households, we're wasting somewhere between 15 and 25 percent of the food that we're buying. You know, that's expensive. I mean, imagine walking out of a grocery store with four bags of groceries, dropping one of them in the parking lot and just not bothering to pick it up, and that's essentially what we're doing in our homes today."

Oliver: "And that's not good when you're throwing away that much food. You're not just being wasteful. You're wining and dining raccoons! ((making raccoon's sound)) 'Oh, this's absolutely lovely!' ((The audience laughs)) ((making raccoon's sound again)) 'Thanks for this, we needed a break from the kids!' ((The audience laughs)) ((making raccoon's sound again)) (Last Week Tonight, 2015)

Wasting food is compared to wining and dining raccoons. The tenor of the metaphor is the act of wasting food, and the vehicle is wining and dining raccoons. The tenor and the vehicle of the metaphor form an incongruous reading because raccoons are treated as human beings who are given much-wasted food. Oliver emphasizes the metaphor by his verbal imitation of raccoons thanking the person who wastes food.

Another metaphor is in Sobhi's satirical advice to his audience in this section from مفيش مشكلة خالص as follows:

$$
\begin{aligned}
& \text { (8) أعزائي المشاهدين، لوكل واحد فيكم - عايز يبقى ما فيش مشكلة خالص (محركاً يده اليده اليمنى يميناً }
\end{aligned}
$$

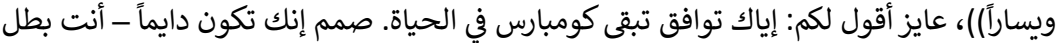

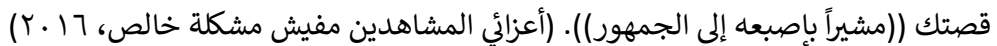

Ladies and gentlemen, if everybody did not want to have any problem at all ((moving his right hand to the right and to the left)), I'd like to tell you: Don't accept being a stunt in life. Insist on always being - the protagonist of your story ((pointing at the audience)).

Sobhi mentions two verbal metaphors about life. Sobhi's first metaphor 'إياك توافق تبقى كومبارس في الحياة' (Don’t accept to be a stunt in life) shows that he compares life with a movie and passive people with stunts. However, his second metaphor 'صمم إنك تكون دايماً أنت بطل قصتك' (Insist on always being the protagonist of your story) shows that he compares life with a story and people as protagonists.

Another example of a metaphor is given from Season 1, Episode 5 of Last Week Tonight with John Oliver. Oliver satirizes the difference between real and virtual friendships. He creates humor using the effect of a metaphor. He delineates the difficulty in getting rid of friends, in 
reality, unlike in the virtual world of social network services (SNS). In this section, Oliver discusses net neutrality and its influence on famous SNS which leads to the metaphor:

(9) Oliver: "But here's the thing: Net neutrality is actually hugely important, essentially it means that all data has to be treated equally no matter who creates it. It's why the internet is a weirdly level-playing field, and start-ups can supplant established brands, that's how Facebook supplanted MySpace, which supplanted Friendster, which supplanted actually having any friends! ((The audience laughs)) D - Do you remember physically having friends? ((The audience laughs)) It was awful! You couldn't ((He moves his index finger forward several times as if he clicks on something)) tap people's faces to make them go away! ((The audience laughs)) (Last Week Tonight, 2014)

Oliver uses a metaphor to compare friendship in reality with virtual friendship online. He compares friendship in reality (tenor of the metaphor) with virtual friendship online (vehicle of the metaphor) by saying "tap people's faces". In the world of computers and technology, 'tap' means to click on something. The word's meaning is the creator of the metaphor and thus the key element of ambiguity.

The following section from El-Barnameg, Season 3, Episode 9, exemplifies another metaphor:

$$
\begin{aligned}
& \text { (10) باسم: “أصل بصراحة النظام القطري زوّدها قوي يعني - شايف نفسه ياما هنا ياما }
\end{aligned}
$$

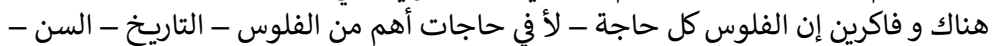

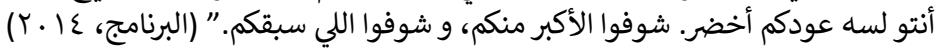

Bassem: "Honestly speaking, the Qatari regime has exaggerated a lot - it's been blowing their own trumpet, and it thinks that money is everything - No, there're other things more important than money - history - age - Your stem is still green. See who's older than you and who's preceded you."

Youssef's words embody satire on the political and economic interference of Qatar in Egypt's affairs. Youssef objects to this interference humorously by satirizing Qatar as a new state and comparing Egypt's history and civilization to its. He also uses the metaphorical idiom 'عودكم أخضر' (Your stem is still green) to show that Qatar is much newer than Egypt in history, civilization, politics, etc. He gives the attributes of a green, unripe crop to Qatar to emphasize his satire on Qatar's recent civilization and history.

Another instance of metaphor is given in this example from Live at the Apollo, Season 6, Episode 3. It was broadcast on December 9, 2010, and 
the guest was the English comedian Greg Davies:

(11) Last year I did some gigs in the city of Bangkok - ((The audience laughs)) - Awesome! The reason I like it, ladies and gentlemen, is in Bangkok I'm not a novelty tour man. In Bangkok, I'm a genuine fairytale giant! ((The audience laughs)) I'm not joking! I was walking through that city like this: ((walking like a giant, raising his right arm))" $\uparrow$ Behold! ((The audience laughs)) Hello, my little fellows! ((The audience laughs)) Who will talk to Gulliver?" ((The audience laughs)) (Arse Raptor, 2010)

Davies narrates an old situation he previously confronted in Bangkok mentioning two verbal metaphors. The first one is in 'In Bangkok I'm a genuine fairytale giant'. The tenor of the metaphor is Davies himself while the vehicle of the metaphor is 'a genuine fairytale giant'. The second metaphor is in 'Who will talk to Gulliver?' The tenor is Davies while the vehicle is Gulliver from Jonathan Swift's Gulliver's Travels. This novel was published in 1726, and it is a satirical novel. When Gulliver travels and becomes shipwrecked, he finds himself on the island of Lilliput where people are 'six inches tall' (Encyclopedia Britannica, 2017). The choice of Gulliver in this metaphor is to foreground the huge gap between the height of Davies and that of the people in Bangkok.

\subsection{Verbal personification}

Personification is a figure of speech in which "human characteristics are attributed to an abstract quality, animal, or inanimate object" (Encyclopedia Britannica, 1998). For example, the sentence 'The desk forgave her for her carelessness' contains a personification of the desk. The desk is given the human characteristic of forgiveness while it is inanimate. Comedians can personify inanimate objects to create humor in comic TV shows. Personification can be incongruous with contradictory readings as well.

An example of verbal personification is mentioned by the English comedian Russell Howard in Example (3) (See 5.1. Collocational Clash). Howard personifies the bacon sandwich as if it is a person hugging a dead pig when he says: "A bacon sandwich is essentially bread giving a dead pig a cuddle". He gives the bacon sandwich the human characteristic of hugging although it is inanimate. Incongruity is foregrounded by such a metaphor. 
A second instance of verbal personification is shown in this section from : أسعد الله مساءكم :

(12) الشتا زي الحرب، وأسلحتك لمواجهة الشتا في البيت هي: أولاً لكلوك، واللي أوعى تفتكر إنك إنكا

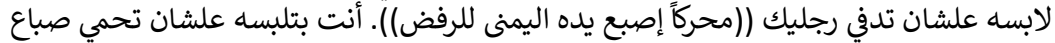

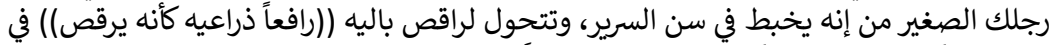

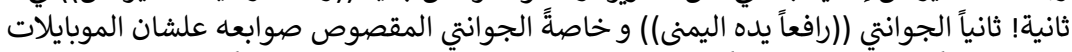

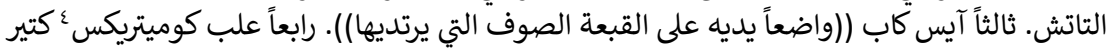

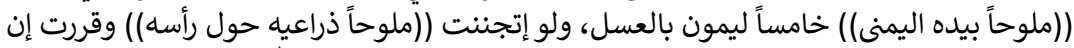
أنت تخرج من البيت، هتحتاج الجزمة السيفتي علشان المطرة. (أسعد الله مساءكم، 10 ـ ب)

Winter is like war, and your weapons to fight winter at home are: First, furry slippers, and don't think you wear them to warm your feet ((moving his finger in objection)). You wear them to protect your feet's little fingers from knocking the edge of the bed and transforming into a ballet dancer ((moving his arms as if he dances)) in minutes! Second, gloves ((raising his right hand)), especially fingerless gloves for smartphones. Third, ice cap ((putting his hands on the woolen hat he wears)). Fourth, many Comtrex packages ((waving his right hand)). Fifth, lemon with honey, and if you went crazy ((moving his arms around his head)) and decided to go out, you'd need safety shoes in case of rain.

Abo Hafiza talks about precautions to get ready for winter. The verbal personification is found in " أنت بتلبسه علشان تحمي صباع رجلك الصغير من إنه إنها "يخبط في سن السرير، وتتحول لراقص باليه في ثانية (You wear them to protect your feet's little fingers from knocking the edge of the bed and transforming into a ballet dancer in minutes). Abo Hafiza personifies a person whose little toe knocks on a bed's edge with as a ballet dancer jumping and raising their hands. The lexical meaning of the verb 'تتحول' (transform) stresses the personification. There are two further verbal techniques to foreground humor on precautions against winter at home. There is a verbal simile in 'الشتا زي الحرب' (Winter is like war) in which

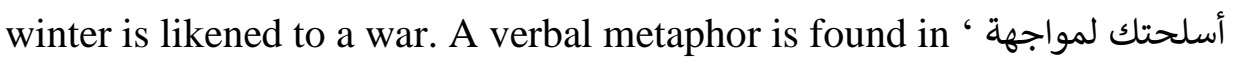
'الشتا في البيت (Your weapons to fight winter at home are). Winter is compared with an enemy fought in a battle. The keyword of the simile is the word 'زي' (like) while those keywords of the metaphor are the lexical meanings of the words 'مواجهة' 'موب' (weapons) and 'أسلحتك' (fight).

A third example of verbal personification is given by Oliver in this section from Last Week Tonight with John Oliver, Season 1, Episode 22.

"كوميتريكس" (Comtrex) is a medicine to heal influenza. 
The president of the Sugar Association in the USA claims that sugar is not responsible for obesity or diabetes. Therefore, Oliver jokes about what he said as follows:

(13) Oliver: "The Sugar Association has gotten a little more sophisticated since then. Here is that current president:" (A scene from another TV show hosting the president of the Sugar Association Andy Briscoe is featured.)

Briscoe: "As it relates to obesity, there's been plenty of science that exonerates sugar. They've clarified sugar is not - er does not contribute to obesity or diabetes -"

Oliver: "Really? ((The audience laughs)) Sugar doesn't contribute to obesity? I'm not saying it's the only culprit, but it's definitely one of the key suspects." (Last Week Tonight, 2014)

Sugar is provided with human characteristics which are contributed by two words of detective lexicon: 'culprit' and 'suspect'. A culprit means a murderer or whoever commits a crime, and a suspect means someone who is alleged to be a culprit. Sugar is then likened to a culprit and a suspect of obesity and diabetes. The choice of detective lexicon emphasizes the verbal personification and thus its humorous effect.

\subsection{Verbal parody}

Parody is another important technique in humor creation. Ross says: "the dictionary definition of parody emphasizes the fact that it is a 'humorous imitation' of a style" (1998, p. 47). For example, a comedian imitates someone's voice, says humorous sentences which a celebrity is known for, etc. Comedians can parody verbally relying on the lexicon which can provide an allusion. According to Ross (1998, p. 11), allusion "involves extra-linguistic knowledge, in other words knowledge about the world. The double meaning may involve reference to a saying or a quotation. If the listener does not share the same awareness of this, the ambiguity cannot be recognized".

This section from Season 7 of Bani Adam Show provides an instance of verbal parody. It was broadcast on April 20, 2016. Adam jokes at the British colonialism of Egypt:

$$
\begin{aligned}
& \text { (14) حتى الإمبراطورية الإنجليزية...اللي كان بيتقال عليها ((مشيراً إلى اليمين)) الإمبراطورية }
\end{aligned}
$$

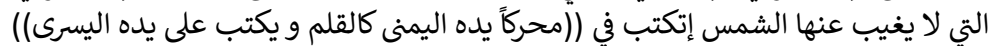

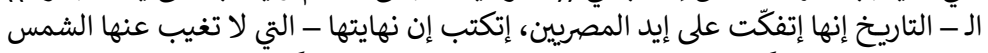

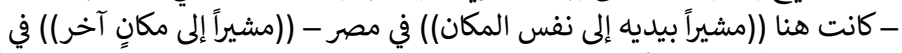

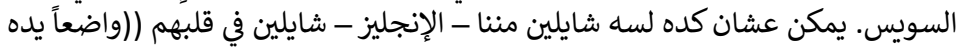




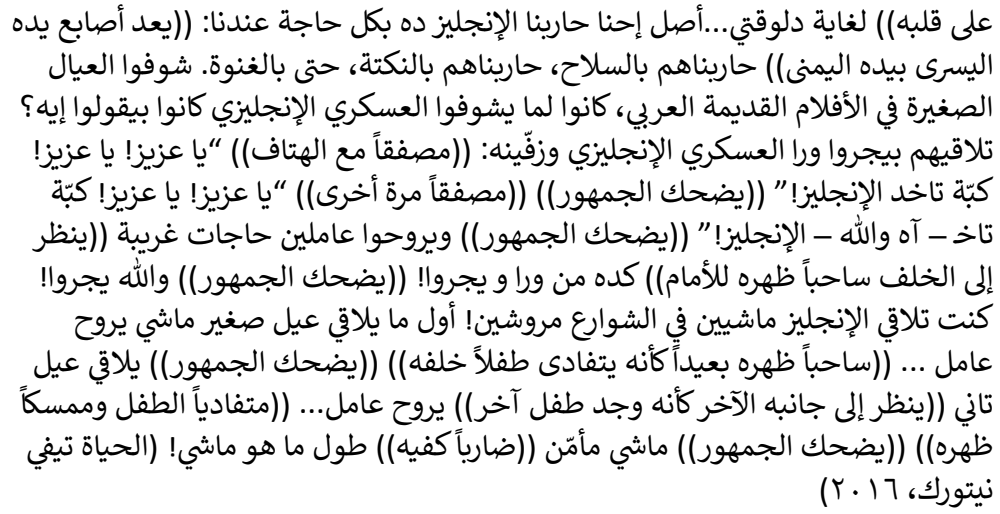

Even er - history recorded that the English Empire ... which was known as ((pointing to the right)) the empire where the sun never sets, came apart because of the Egyptians. It was recorded that the empire's end - where the sun never sets - was here ((pointing at where he is)) in Egypt - ((pointing at another place)) in Suez. Maybe this's the reason why they still have a grudge against us - the English - they hold a grudge ((putting his hand on his chest)) until now ... We fought the English by all the means we have: ((putting his left hand's fingers on his right hand)) We fought them by weapons, by jokes, and even by songs. See the children in old Arabic movies: when they saw an English soldier, what did they say? You find them running behind the English soldier, surrounding him and chanting: ((clapping with the chant)) "Aziz! Aziz! May the English go to hell!" ((The audience laughs)) ((clapping again)) "Aziz! Aziz! May the English go - really - to hell!" ((The audience laughs)) They did strange things ((looking at the back, withdrawing his back to the front)) at the back and ran away! ((The audience laughs)) Really, they ran away! You find the English walking in panic in streets! When they found a child walking, the English ... ((He withdraws his back as if he avoids the child behind him)) ((The audience laughs)) When he found another child ((looking aside as if he found another child)), he ... ((avoiding the other child by holding his back)) ((The audience laughs)) He walked cautiously ((clapping)) whenever he walked!

Adam recalls back the past when the British colonized Egypt from 1882 till 1952 (Selim, 2019). He tells the audience the reason why the British might have held grudge against the Egyptians. This grudge dates back to the way the Egyptians fought against the British during the colonial period. Adam says: “ أصل إحنا حاربنا الإنجليز ده بكل حاجة عندنا: حاريناهم" (We fought the English by all the means we have: We fought them by weapons, by jokes, and even by songs). Through his utilization of his body language, he manages to portray an image of how the Egyptians strived against the British colonialism. 
Adam parodies verbally how Egyptian children faced the British soldiers in old Egyptian movies. Adam says that the children walk behind an English soldier and chant these phrases: 'يا عزيز! يا عزيز! كُبّة تاخد الإنجليز 'Az' (Aziz! Aziz! May the English go to hell). Adam parodies non-verbally

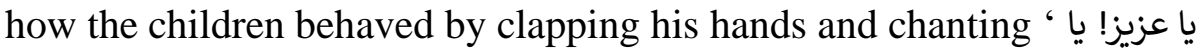
'عزيز! كُبة تاخد الإنجليز! twice.

Another example of verbal parody is presented by the British comedian Steven K. Amos in Episode 5 from Live at the Apollo, Season 6:

(15) From as I was a young kid saying to my Dad: “ $\uparrow$ Dad! Dad! There’re so many kids in the family, there's no - there's no money; no enough money! Can I have some pocket money? ((raising his right hand begging))" My dad would look at me ago: " (Changing voice pitch, and looking aside) $\uparrow$ Shut up, bastard! ((The audience laughs)) Your pocket is for your hand ((turning to the audience and raising his right hand))" ((The audience laughs)) (Arse Raptor, 2010)

Amos imitates a situation which he experienced when he was young. $\mathrm{He}$ asked his father for some pocket money, but his father refuses incongruously by saying: "Shut up, bastard! Your pocket is for your hand." The polysemous senses of 'pocket' are the source of incongruity. 'Pocket' means not only a part of clothing in which hand or other things can be put, but also an amount of money to be spent. Amos changes his voice pitch twice. He firstly raises voice pitch when he imitates his voice as a child on saying "Dad! Dad! There're so many kids in the family, there's no - there's no money; no enough money! Can I have some pocket money?" He secondly changes his voice when he imitates his father's reply: "Shut up, bastard! Your pocket is for your hand." These sentences represent a verbal parody while the change in voice pitch represents non-verbal parody.

A third instance of verbal parody is performed by Adam in Bani Adam Show, Season 6, Episode 9. He parodies the TV show الاتجاه المعاكس (The Opposite Direction) broadcast on Al-Jazeera Channel as follows:

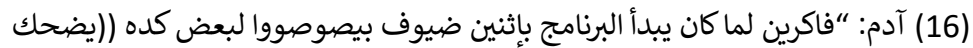

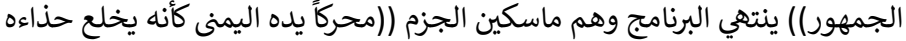

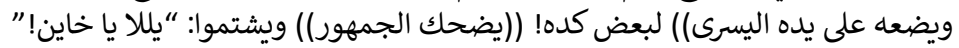

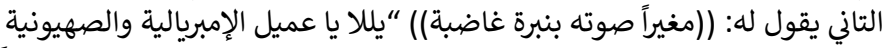

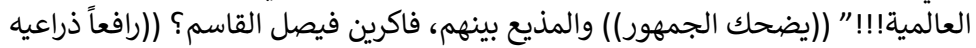

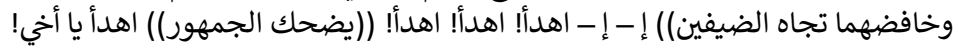




$$
\begin{aligned}
& \text { اهدأ يا أخي! ((محركاً ذراعه اليسرى للأعلى وللأسفل)) كفى! كفى! كفى كفى! (إضضحك }
\end{aligned}
$$

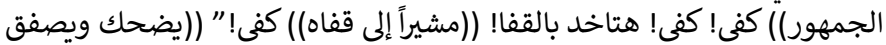

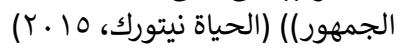

Adam: "Do you remember when the show starts with two guests twittering to each other like this ((The audience laughs)) and the show ends in that they hold their shoes for each other ((moving his right hand as if he takes off his shoe and puts it on his left hand)) like this! ((The audience laughs)) They insult each other: 'Get out of here, traitor!' The other says ((changing his voice pitch in anger)): 'Get out of here, the agent of imperialism and world Zionism!!!' ((The audience laughs)) The presenter between them, do you remember Faisal ElQasim? ((ascending and descending his hands toward the guests)) ' $\mathrm{C}-\mathrm{C}-$ Calm down! Calm down! Calm down! ((The audience laughs)) Calm down, brother! Calm down, brother! ((ascending and descending his right arm)) Stop! Stop! Stop! ((The audience laughs)) Stop! Stop! Or you will be smacked! ((pointing at his nape)) Stop!'” ((The audience laughs and applauds))

Adam describes how debates usually run in الاتجاه المعاكس. He asks the audience if they remember when the guests at the beginning of the show behave quietly and meekly like twittering birds. Adam uses the Arabic onomatopoeic expression of the twittering of birds 'بيصوصووا'. He creates a humorous metaphor of the guests giving them a trait of birds: twittering. It connotes the guests are so calm and peaceful in the beginning of the show. However, the opposite image is given when the guests start to fight as the show progresses. The guests fight as if they hold their shoes and threatening to throw them on each other. Adam then describes how the guests start to insult each other. The final phase of the verbal parody is when Adam imitates the host of the show, Faisal ElQasim, and his reaction to the fight between the guests. He says " $-1-1$ ”'اهدأ! اهدأ! اهدأ! اهدأ يا أخي! اهدأ يا أخي! كفى! كفى! كفى! كفى! كفى! هتاخد بالقفا! كفى! ('C $\mathrm{C}-\mathrm{C}-\mathrm{Calm}$ down! Calm down! Calm down! Calm down, brother! Calm down, brother! Stop! Stop! Stop! Stop! Stop! Or you will be smacked! Stop!). Adam says the previous lines with an incongruous sentence 'هتاخد بالقفا' (You will be smacked). The sentence is humorous because the expression is Egyptian, and it is too incongruous to be said in a debate show.

Verbal parody can take place via a parody of songs' lyrics. Comedians often sing the exact lyrics of famous songs or with amusingly incongruous edition in the lyrics. The Australian comedian Adam Hills 
provides an example of verbal parody in this section from Live at the Apollo, Season 9, Episode 4:

(17) I love music and I don't understand it. I'm completely blown away by it, and that's why I think it's brilliant. And I've seen the power of music around the world. I've seen music bring people together regardless of nationality. I've seen Jon Bon Jovi is the universal constant - ((The audience laughs)) whether or not you like his music if you can sing a Jon Bon Jovi song anywhere in the world, you will bond a room full of people instantly. ((The audience laughs)) Honestly, I was back so - I was doing shows in Belgium once, and I was backstage with a group of Belgian comics. They were five Belgian comedians, me, and Michael McIntyre. And I'm thinking: "What are you - I've got nothing in common with these guys. What, How do you - how do you start a conversation with a Belgian? So I was like" ((changing voice pitch)) Oh! ((blowing)) Do you like waffles ((frowning))?" ((The audience laughs)) It's this weirdest thing where everyone was really nervous; no one knew what to say and one of the Belgian guys - I can only assume out of nerves - just started singing to himself under his breath. In the middle of this crowded room, everyone's going quiet, this one guy just went: “((imitating Bon Jovi's voice)) This Romeo is bleeding ((The audience laughs)) but you can't see his blood (The audience laughs) It's nothing but some feelings ((The audience laughs)) That this old dog - kicked up ((The audience laughs))" And then he must have suddenly realized what he was doing because he looked at me and went ((opening his mouth wide)) "Oh!” ((looking downwards in shyness)) ((The audience laughs)) So I looked back across the room, and I just went: "((imitating Bon Jovi's voice)) It's been raining since you left me ((The audience laughs)) Now I'm drowning in the flood ... You see I've always been a fighter, but without you I give up. ((The audience laughs))" And he just got me, looked and said "You're not serious, are you?" ((The audience laughs)) I got him a look and said "I am, if you are." He took a step and he went: "((imitating Bon Jovi's voice)) Now I can't sing a love song ((The audience laughs)); like the way it's meant to be." And I thought "I'll see you and raise you, my friend." ((The audience laughs)) So I just went "((looking aside)) ((imitating Bon Jovi's voice)) And I guess I'm not that good anymore, but baby that's just me." There was a pause then everyone in the room did the chorus. ((The audience laughs)) Me, five comedians, and Michael McIntyre just went: "((bending his body) $) \uparrow$ And IIIIIIIIIIIIIIIIIII ((The audience laughs)) will looooove yoooooou, babyyyyyyyyyyy! ((The audience laughs)) $\uparrow$ Ooooooooooooh" ((The audience laughs)) We're bonded. We're Jon-bonded. ((The audience laughs)) (Arse Raptor, 2013)

Hills emphasizes humorously how Bon Jovi songs unite people all over the world. He narrates a situation in which Bon Jovi's song 'Always' creates an atmosphere of solidarity between him, Michael McIntyre (another comedian), and other Belgian comedians. A direct allusion to Bon Jovi's song 'Always' is provided, and the lyrics which are sung by Hills and the other comedians is as follows: 
This Romeo is bleeding,

But you can't see his blood

It's nothing but some feelings

That this old dog kicked up

It's been raining since you left me

Now I'm drowning in the flood

You see I've always been a fighter

But without you I give up

Now I can't sing a love song

Like the way it's meant to be

Well, I guess I'm not that good anymore

But baby, that's just me

(Chorus) Yeah I, will love you, baby (Bon Jovi Lyrics, n.d.)

The lyrics of the song are romantic. It deals with a person who is abandoned by his beloved. The person imagines his beloved next to him, and he promises his beloved to continue to love her. The lyrics are not related to the context of Hill's situation with the Belgian comedians, and this is the source of incongruity in Example (17): A romantic song becomes an icebreaker and connects strange comedians with each other by singing the song together.

'كنتِ فين' Abo Hafiza performs a parody of an old romantic song entitled (Where Were You) sung by the Egyptian singer Abdel Haleem Hafiz. In this section from أسعد الله مساءكم, Season 1, Abo Hafiza creates humor by changing the lexicon of the lyrics to emphasize humor by parody. The lyrics of the old song are romantic as follows:

$$
\begin{aligned}
& \text { كنت فين وانا فين جيت لي منين } \\
& \text { والأيام دي كانت غايبة عني فين فين فين } \\
& \text { نظرة عين فايتة القلب وفية جراية جرحين فين }
\end{aligned}
$$

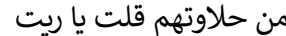

$$
\begin{aligned}
& \text { كان لي قلبين (كلمات اغنية 'كنت فين' عبد الحليم حافظ ، . (n.d. }
\end{aligned}
$$

Where were you? Where am I? Where did you come from?

Where were these days away from me?

Heart missed a look, broken twice

As they are sweet, I said I wish

I had two hearts

Abo Hafiza's parody of the song is as follows:

$$
\begin{aligned}
& \text { (18) كونتي فين } \\
& \text { لاست سين } \\
& \text { مالساعة إتنين } \\
& \text { كنتي عاملة }
\end{aligned}
$$


Where were you

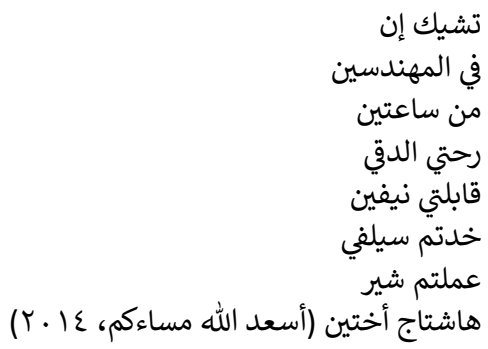

Last seen

Since two o'clock

You were doing

Check-in

In El-Mohandesin

Two hours ago

You went to Dokki

You met Nevin

You took Selfie

You shared it

With hashtag "Two sisters"

The lexicon of the song's lyrics plays an important role in parody. Words of SNS, especially Facebook, are used in the parody. Here is a list of such words categorized by their parts of speech. The equivalent words in English are provided because the words are transliterated from English into Arabic.

Table 1. The parts of speech of SNS words

\begin{tabular}{|c|c|c|c|}
\hline $\begin{array}{l}\text { Words and Their } \\
\text { Parts of Speech }\end{array}$ & Noun & Verb & $\begin{array}{l}\text { Modifier } \\
\text { (Adjective or } \\
\text { Adverb) }\end{array}$ \\
\hline \multirow{4}{*}{ Words } & تشيك إن (Check-in) & سين (Seen) & لاست (Last) \\
\hline & سيلفي (Selfie) & & \\
\hline & شير (Share) & & \\
\hline & هاشتاج (hashtag) هاج & & \\
\hline
\end{tabular}

As shown above, such a lexicon creates a parody of romance. Romance in the past was different from how it might be nowadays. The influence of SNS has been so overwhelming that love might take place on Facebook, for instance, instead of actual meeting. Consequently, Abo Hafiza's song is a parody of an old song about romance to satirize virtual romance which happens on SNS. 
Another example of verbal parody by a song is given in this section from 'علّي صوتك بالغنا' The lyrics of the original song are from أسعد الله مساءكم (Raise Your Voice in Singing) by the Egyptian singer Muhammad Mounir:

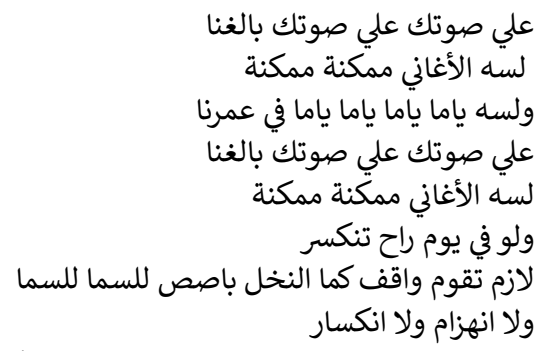

ولا خوف ولا ولا حلم نابت في الخلا في الخلا (كلمات اغنية علي صوتك بالغنا، .n.d)

Raise your voice, raise your voice, in singing

Songs are still possible, possible

It's still, still, still, in our life

Raise your voice, raise your voice, in singing

Songs are still possible, possible

If you're defeated sometimes

You should stand confidently as tall as a palm

No defeat, no retreat

No fear, no, no dream growing in the dark, in the dark

Abo Hafiza's parody of the song is as follows:

$$
\begin{aligned}
& \text { (19) علي صوتك علي صوتك في الأجوبة } \\
& \text { شكل السنة دي مهببة مهببة } \\
& \text { و بالسنة دي لامالامة لامة الترم ده دهية } \\
& \text { علي صوتك علي صوتك في لالك في الأجوبة } \\
& \text { شكّل السنة دي مهببة مهببة صوتية }
\end{aligned}
$$

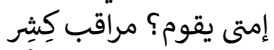

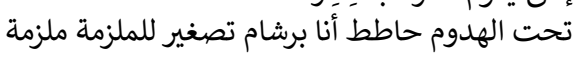

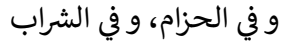

$$
\begin{aligned}
& \text { عالمنقلة كاتب أنا حل المسألة المسألة (أسعد الله مساءكم، } 10 \text { • ؟ ) }
\end{aligned}
$$

Raise your voice, raise your voice, in answers

This year seems awful, awful

This year no blame, no blame for this term

Raise your voice, raise your voice, in answers

This year seems awful, awful

When will they go away? A frowning supervisor

Underneath clothes, I have a summary cheat sheet of the sheets, of the sheets

On belt, and in socks

On the protractor I have the answer of the problem, the problem 
The choice of the lexicon helps to create the parody song. The lexicon focuses on answers, cheat, and examination.

Table 2. The parts of speech of the parody song's lyrics

\begin{tabular}{|c|c|c|}
\hline $\begin{array}{l}\text { Words and Their Parts of } \\
\text { Speech }\end{array}$ & Noun & $\begin{array}{l}\text { Modifier (Adjective or } \\
\text { Adverb) }\end{array}$ \\
\hline Words & $\begin{array}{l}\text { مراقلامة (blame) } \\
\text { مراقبة (supervisor) } \\
\text { برشام (cheat sheet) } \\
\text { الملزمة (sheets) } \\
\text { المسألة (the answer of } \\
\text { the problem) }\end{array}$ & $\begin{array}{l}\text { كِثِب (frowning) } \\
\text { كهببر (awful) }\end{array}$ \\
\hline
\end{tabular}

The role of verbal parody of such a song is to foreground satire on cheating in school examinations.

Verbal parody can take place by replacing a serious comment from another TV show, movie scene, etc. with a humorous comment. This section from Season 1 of أسعد الله مساءكم Shows such a technique of verbal parody. A scene of an interview with the Argentinian soccer player Lionel Messi is edited. An actor's voice is applied on Messi's real voice instead. Abo Hafiza imagines what would happen if Egypt hosted the World Cup Championship one day and how interviews with soccer players would be like:

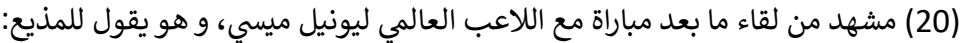

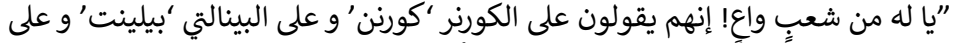

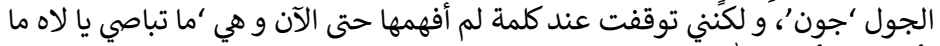

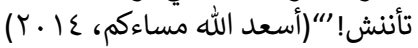

A scene of a post-match interview with the famous soccer player Lionel Messi is shown, telling the reporter: "How aware the people are here! They call a corner 'cornan', a penalty 'belent', and a goal 'goan'. However, I haven't understood an expression until now, which's 'Pass the ball, dude, and don't be selfish!”

The soccer lexicon of Egyptian colloquial is the comic element in the previous section. Table 3 delineates a comparison between the lexicon of soccer and their variations in Egyptian colloquial.

The comparison between such a lexicon and its variations satirizes Egyptian colloquial. As previously mentioned, the variations feature changes in English sounds of the transliterated words. The parody 
delineates Messi's wonder about a certain phrase in Egyptian colloquial: " ما تباصي يا لاه ما تأننش". The phrase can be roughly translated as 'Pass the ball, dude, and don't be selfish'.

Table 3. Lexicon of soccer in Egyptian colloquial and their variations

\begin{tabular}{ll}
\hline $\begin{array}{l}\text { Lexicon of Soccer in Egyptian } \\
\text { Colloquial }\end{array}$ & $\begin{array}{l}\text { Variations of the Lexicon in Egyptian } \\
\text { Colloquial }\end{array}$ \\
\hline كورن (corner) & بينالتي (penalty) جورن (goal) $ج و$ (goan) \\
\hline
\end{tabular}

The verb 'تأنتش' shows a morphological derivation. The verb is derived from the adjective 'أناني' (selfish). By stressing the letter 'b' and by Egyptian inflection of negation ' $ش$ ', the adjective becomes a verb. The particle ' 1 ' is added before the verb for negation. Consequently, the lexicon of the humorous comment applied on the interview with Messi is a basic component of verbal parody.

\subsection{Extended imagination}

A seventh technique of creating humor is extended imagination in which comedians can imagine various scenarios. They narrate imaginary scenarios based on the various issues they joke about. Such scenarios are so incongruous that the audience finds them funny and laughs. These imaginary scenarios are the basis of extended imagination.

Extended imagination can apply to the art of monologue. Monologue "is meant to be heard, has that sense much more often than not, and is especially used of a talker who monopolises conversation, or of a dramatic performance or recitation in which there is one actor only" (Fowler, 2009, p. 611). Since comedians usually joke solely in the following examples, their style of humor and monologue can converge. To clarify the source of extended imagination, the following words of the Egyptian actress Thoraya Helmy is quoted from an interview as follows:

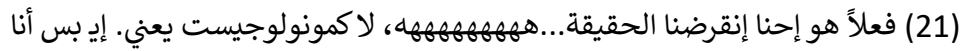

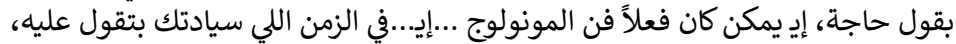

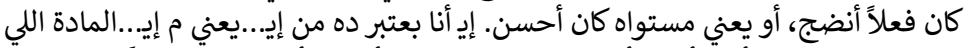

$$
\begin{aligned}
& \text { إحنا بنقول منها، إي أو أتتأليف أو الكلمات. إي...كانوا بيألفولنا أكبر كتّاب تقريباً ... (اليوم }
\end{aligned}
$$

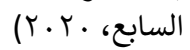


We've become extinct actually ... hahaha, as monologists, I mean. Er, but I want to say something, er maybe the art of monologue ... er ... in the period which you mention, was more flourished, or its level was better. Er, I consider this because of, er ... the material which we were reciting from, er, the composition or words, er... famous authors were often composing for us ...

Thoraya Helmy, as a humorous monologist, emphasized the importance of skillful composition for the success of a monologue. According to her opinion, the reason why the art of monologue started to diminish in Egypt is the lack of creativity in composition. Skillful composition can be derived from wide imagination. Hence, it can be inferred that humor in comic TV shows, like monologues, is usually the result of extended imagination by skillful composition or improvisation.

\section{This section from Bani Adam Show, Season 2, Episode 31, exemplifies} the role of extended imagination. Adam suggests how referees in Egypt can be guarded after soccer matches:

$$
\begin{aligned}
& \text { (22) آدم: "مناسبة الحكّام اللي بيتضريوا في كل ماتش دول ل... ((يضحك الجمهور)) }
\end{aligned}
$$

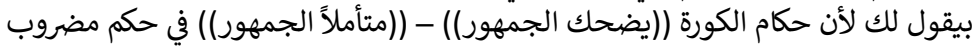

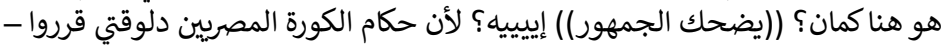

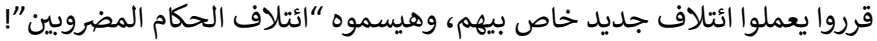

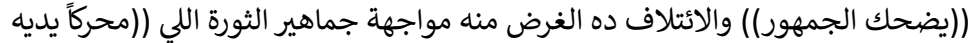

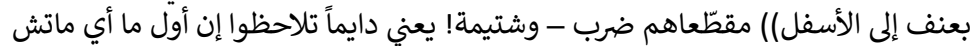

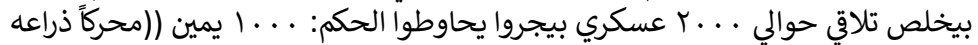

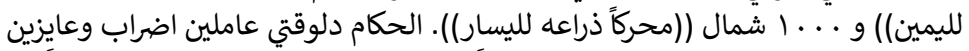

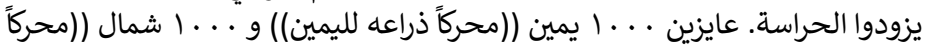

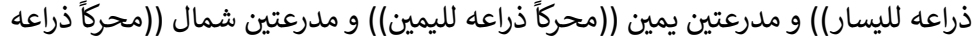

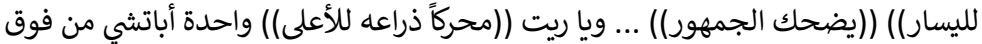

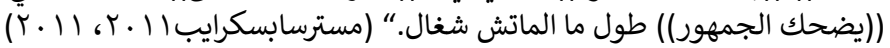

Adam: "Considering the referees who are beaten in every soccer match ... ((The audience laughs) ) - Because soccer referees ((The audience laughs)) ((looking at the audience)) Is there a beaten referee attending here as well? ((The audience laughs)) Eeeeh? Because the Egyptian soccer referees decided - decided to form a new association especially for them, and they will call it The Beaten Referees Association! ((The audience laughs)) The aim of this association is facing the Revolution's supporters who ((moving his hand violently downwards)) beat and curse them - severely! I mean, you always notice when the match ends, you find about 2000 soldiers running and surrounding the referee: 1000 on the right ((moving his arm to the right)) and 1000 on the left ((moving his arm to the left)). Now, the referees are on strike and want to increase security. They want 1000 soldiers on the right ((moving his arm to the right)), 1000 on the left ((moving his arm to the left)), two armored cars on the right ((moving his arm to the right)), two armored cars on the left ((moving his arm to the left)) ... and hopefully ((moving his arm 
upwards)) an apache plane flying above during the match."

Adam talks about the problem of referees in Egypt who got beaten by supporters after soccer matches in the aftermath of the Revolution of January 25, 2011. Adam imagines a further scenario. He describes how security forces are too many to guard the referees when they try to exit the stadium after any soccer match. To stress incongruity, he extends the scenario in a rather imaginary way to make the audience laugh. He increases the ways of guarding the referees on their exit from the stadium not only by 2000 security soldiers but also by two armored cars on the left, two others on the right and one Apache plane flying above the stadium during the match.

The American comedian Martha Kelly exemplifies extended imagination in this section from Late Night with Conan O'Brien, Season 9, Episode 142:

(23) Um ... I have an idea of how I could, er, make a living without actually having to work. Um ... I think that I'm gonna try my hand at being a motivational speaker ... ((The audience laughs)) ... um ... just hear me out. ((The audience laughs)) Um, I - er - I don't know if you all know who Tony Robbins is, but he's kind of a personal hero of mine because - he's figured out how to make a living by sharing his life skills with people and charging a fee, and I think that I could probably do the same thing. So, this summer for the first time ever I'm offering my encounters with depression-power weekend. ((The audience laughs)) And - er - we're gonna have several seminars including "Potato Chips", "Friend or Foe" ((The audience laughs)) ... um, "Going Outside", and other tales of courage ... ((The audience laughs)) and then the last one for the weekend is called "Sleeping It Off: It's Never Too Early to Go Back to Bed". ((The audience laughs)) So, you can sign up for that on the way out. ((The audience laughs)) (Team Coco, 2019)

Kelly's extended imagination lies in her desire to be a motivational speaker drawing her inspiration from the American public speaker and author Tony Robbins. She incongruously believes that motivational speaking brings money with lesser effort. She says that Robbins "figured out how to make a living by sharing his life skills with people and charging a fee", and she thinks of following his footsteps. She pretends humorously that her seminars would inspire people to get over depression, and the seminars are held in summer. She calls her seminars with incongruous titles such as 'Potato Chips', 'Friend or Foe' (an 
American game show), 'Going Outside', and 'Sleeping It Off: It's Never Too Early to Go Back to Bed'.

\section{A fourth instance of extended imagination is in this section from Bani}

\section{Adam Show, Season 6, Episode 2:}

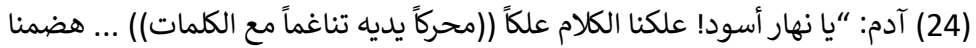

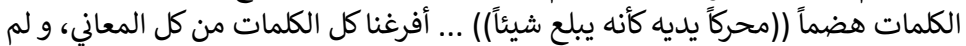

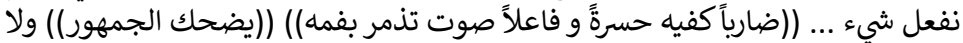

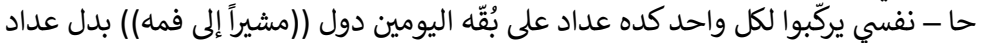

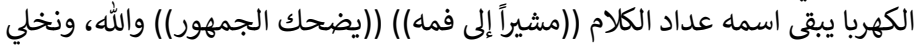

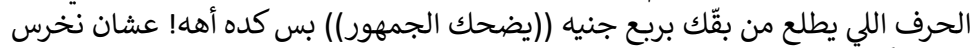

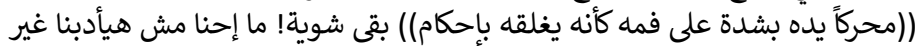

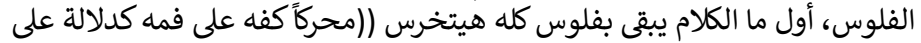

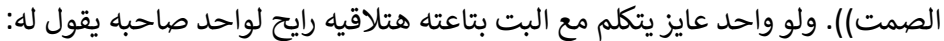

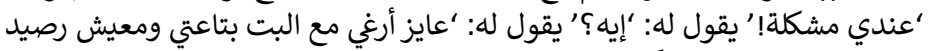

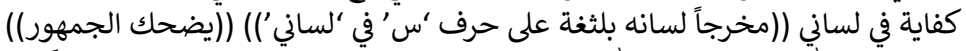

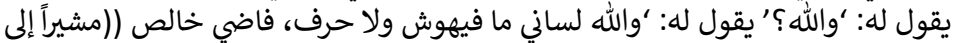

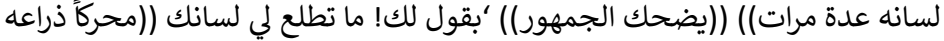

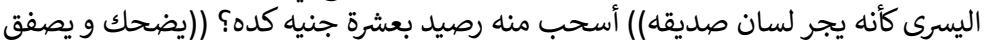

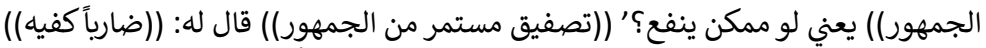

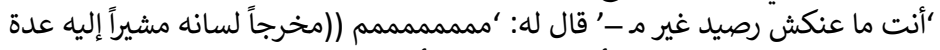

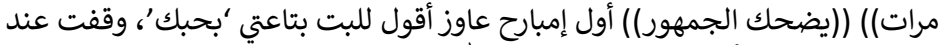

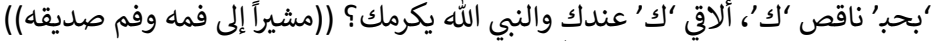

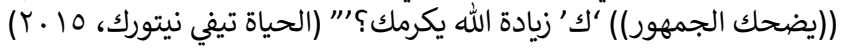

Adam: "Oh my God! Words were chewed so much ((moving his hands along with what he says)) ... The words were digested so much ((moving his hands as if he swallows something)) The words were emptied from all meanings and nothing was done ... ((clapping his hands and grumbling in misery)) ((The audience laughs)) Or - I wish a meter was attached to everybody's mouth nowadays ((pointing at his mouth)) instead of electricity meter. It should be called the talking meter. ((pointing at his mouth)) ((The audience laughs)) Really, any letter coming out of your mouth would cost twenty-five piasters ((The audience laughs)), and that's it to shut up ((moving his hand over his mouth as if he shuts it)) for a while! Nothing behaves us except paying money. When talks cost money, everyone will shut up ((moving his hand on his mouth to show silence)). If a man wants to talk to his girlfriend, you'll find him going to his friend and telling him: 'I've a problem!' He says: 'What?' He tells him: 'I wanna chat with my girlfriend but don't have enough credit in my tongue ((sticking out his tongue and lisping the letter ' $\omega$ ' pronouncing it as ' $ث$ ' in the word 'لسان') ((The audience laughs)) He replies: 'Really?' He says: 'Really, my tongue has no letters ((pointing to his tongue several times)) ((The audience laughs)) 'OK, what about sticking out your tongue ((moving his left arm as if he pulls his friend's tongue)) to get a ten-pound credit from it? ((The audience laughs and applauds)) May I do, please? ((The audience continuously applauds)) He replied: ((clapping)) 'Don't you have any credit but -' He said: 'mmmmmmmm ((sticking out his tongue and pointing at it several times)) 
((The audience laughs)) The day before yesterday, I wanted to tell my girlfriend 'I love you', I stopped at 'yo' and ' $u$ ' remained. Do you have a 'u', please? ((pointing at his and friend's mouth)) ((The audience laughs)) Another 'u', please?'

In a tone of simultaneous annoyance and humor, Adam satirizes the exaggeration of the Egyptian mass media in approaching news. He provides an incongruous solution to the problem so that the Egyptians control the way they talk about news. He suggests that a talking meter should be attached to the mouth of the Egyptians. Every uttered letter costs twenty-five piasters so that talks become under control. It is exactly as similar as the electricity meter. To support his opinion, Adam supposes a dialogue between two friends. One of them has run out of credit of letters. To re-charge new credit, he asks his friend for help. Adam plays the role of both speakers simultaneously. The dialogue is an extended imagination by which Adam emphasizes the importance of controlling talk and satirizes gossip in Egypt.

\subsection{Cultural barriers in comic TV shows}

The elements of cultural literacy play an important role in understanding verbal humor across cultural barriers. The following table states such elements to identify cultural barriers in comic TV shows. The success of verbal humor can be seen in the previous analysis owing to an ultimate cultural literacy of the following news, events, etc. as follows.

Table 4. Elements of cultural literacy in collocational cash

\section{Elements of Cultural Literacy in the Elements of Cultural Literacy in the Arabic Examples English Examples}

1. Example (1): The connotations of the colors 'black' and 'white' in Egypt

2. Example (5): Nanotechnology

3. Example (8): Cinema and stories

4. Example (10): Plants

5. Example (12): Ballet

6. Example (14): The British colonialism of Egypt from 1882 till 1952

7. Example (16): The TV show 'الاتجاه المعاكس' (The Opposite Direction) broadcast on AlJazeera Channel
1. Example (2): The World Economic Forum, Bill Gates

2. Example (3): Guilt-free sandwiches and pork

3. Example (4): The danger of using lighters

4. Example (6): Inaccuracy in scientific research

5. Example (7): Raccoons

6. Example (9): Virtual friendships on SNS,

7. Example (11): Jonathan Swift's Gulliver's Travels

8. Example (13): Detective fiction 
8. Example (18): Abdel Haleem Hafiz's song 'كنتِ فين' (Where Were You) and SNS

9. Example (19): Muhammad Mounir's song 'علي صوتك بالغنا' (Raise Your Voice in Singing) and cheating in school exams

10. Example (20): the Argentinian soccer player Lionel Messi

11. Example (22): Problems of soccer referees after the Revolution of January 25, 2011 and military vehicles

12. Example (24): The disadvantages of gossips and electricity meter
9. Example (15): Pocket money

10. Example (17): Bon Jovi's song 'Always'

11. Example (23): Motivational speakers such as Tony Robbins

On the one hand, an elaboration of a few Arabic examples is provided to clarify the function of cultural literacy. In Example (1), Sobhi creates humor playing with the connotations of 'black' and 'white' in Arab culture. 'Black' connotes 'bad', 'evil', 'negative', and 'dark' while 'white' connotes 'good', 'fair', 'positive', and 'light'. Sobhi utilizes such a contrast to emphasize nobody is perfect: Even white things are not always as pure as they seem to be. Consequently, elements of cultural literacy vary from a country to another. In Example (5), Adam's humor is based on essential knowledge about nanotechnology and how it works. It is background knowledge based on following up news and further reading, for instance. Adam's incongruous punch line is based on such مnowledge about nanotechnology when he says: " ما أنت ممكن الصبح تقوم م'تلعب في ذرات أخوك تحوله لابن خالتك! وأنت مش واخد بالك! (You can modify the atoms of your brother in the morning so that you can convert him into your cousin! While you're not aware of that!). In Example (6), however, Oliver's comment requires knowledge of the frequent inaccuracy in scientific research causing inaccurate results.

In Example (8), knowledge about the roles of actors in movies is necessary to perceive the verbal metaphor 'إياك توافق تبقى كومبارس في الحياة (Don't accept to be a stunt in life). Such knowledge of the roles of characters in stories is also necessary to perceive the verbal metaphor 'صمم إنك تكون دايماً أنت بطل قصتك' (Insist on always being the protagonist of your story). Despite the seriousness of this example, such verbal 
metaphors are crucial for enhancing didactic goals of humor in comic TV shows. In Example (10), planting is important as an element of cultural literacy in the idiom 'عودكم أخضر'. When a plant is not ripe enough, its color is green. If the audience is not aware of this metaphoric idiom, they will not understand Youssef's satirical message about Qatar. The satirical message is as follows: Qatar is much newer than Egypt's civilization and history, and Egypt is incomparable.

In Example (14), knowledge about the British colonialism of Egypt is يا عزيز! يا عزيز! كُبّة ' تاخد ' 'تاخد الإنجليز! This phrase is composed by Aziz El-Masry, a member of the Free Officers movement in Egypt. The phrase enthused about striving against the British colonialism ( $\uparrow$ • (صدى البلد، T).

Examples (18) and (19) necessitate knowledge about two Egyptian songs. In Example (18), Abo Hafiza's parody of love on SNS would not be understood if Abdel Haleem Hafiz's song 'كنتِ فين' (Where Were You) was not familiar. In Example (19), likewise, Abo Hafiza's parody of cheating during school examinations would not be understood if Muhammad Mounir's song 'علي صوتك بالغنا' (Raise Your Voice in Singing) was not familiar. Despite editing both songs' lyrics to deliver verbal parody, the music of the songs is used without any edition. Example (24) requires familiarity with the exaggeration of gossips among many Egyptians. If the audience did not know the electricity meter, they would not discern Adam's suggestion about the talking meter to control people's gossips.

On the other hand, an elaboration of a few English examples is provided to clarify the function of cultural literacy. In Example (7), knowledge about raccoons which often eat wasted food in the USA is essential to understand Oliver's metaphor 'You're not just being wasteful. You're wining and dining raccoons'. Yet, in Example (9), the world of SNS and virtual friendships in comparison to making friends, in reality, is the basic element of cultural literacy. In Example (11), knowledge about Jonathan Swift's Gulliver's Travels is important. Davies utilizes his characteristic feature of height to form verbal metaphors comparing himself to Gulliver with the Lilliputs. 
In Example (13), knowledge of detective fiction plays an important role in discerning Oliver's humorous comment about sugar. The words 'culprit' and 'suspects' are the keys to understand his personification. In Example (15), the polysemy of 'pocket' has to be known to discern Amos's humor. In Example (17), the audience has to be familiar with Bon Jovi's song 'Always'. Its significance lies in its incongruity to unite Hills and McIntyre with Belgian comedians whom they have not met before. The song is romantic, and it does not have any connection with comedians who attempt to get on with each other. In Example (23), familiarity with motivational speakers is required. Kelly mentioned American-specific items such as Tony Robbins and 'Friend or Foe' game show. She provides such key elements to extend her imagination about the incongruous titles of her seminars when she becomes a motivational speaker.

The previously mentioned cultural literacy usually governs how comedians create and adapt their humor. This is the reason why English comic TV shows, for example, are different from Arabic comic TV shows. Although the examples from the comic TV shows share the same verbal techniques of humor, the resulted humor is different. The audience of English comic TV shows cannot understand Arabic comic TV shows and vice versa unless there is sufficient cultural literacy. Such sufficient cultural literacy can make the audience break cross-cultural barriers to understanding international comic TV shows. Humor is culturallyspecific despite similarities among its verbal techniques.

\section{Conclusion}

Verbal techniques of humor creation are analyzed in this study. Data from Arabic and English comic TV shows are randomly selected to approach the role of verbal humor in comic TV shows. The analysis starts qualitatively, and the approach to such techniques is semantic to shed light on ways of playing with the word or phrasal meaning (i.e. denotation, connotation, and collocation), figurative language (i.e. verbal tropes such as simile, metaphor, and personification), and parody. The techniques of verbal humor creation are similar as seen in the examples. There is a reliance on the comedian's style of joking, body language, etc. 
However, such reliance is not as noticeable as the reliance on the semantics of words or phrases (i.e. denotation, connotation, and collocation), figurative language, and parody. Consequently, semantics is sufficient enough to approach many techniques of verbal humor as shown in the analysis. Two exceptions are verbal and extended imagination, and they are analyzed as techniques of verbal humor. Cultural barriers are represented in the role of cultural literacy. Cultural literacy is approached to maintain a simultaneous comparative approach to Arabic and English humor in comic TV shows. The approach to cultural barriers stresses the role of culture in verbal humor. Thus, the contribution of the study is to provide a more profound analysis of the way humor can be created verbally and semantically across cultural barriers in comic TV shows.

\section{References}

Attardo, S. (1994). Linguistics theories of humor. Berlin: Mouton de Gruyter.

Attardo, S. (2001). Humourous texts: Semantic and pragmatic analysis. Berlin: Walter de Gruyter.

Bon Jovi Lyrics. (n.d.). Retrieved February 17, 2020 from https://www.azlyrics.com/lyrics/bonjovi/always.html

Carrell, A. T. (1993). Audience/community, situation, and language: A linguistic/rhetorical theory of verbal humour (Unpublished $\mathrm{PhD}$ Thesis). Purdue University, Indiana. Available from ProQuest Dissertations and Theses database. (Accession Order No. 9403662)

Chandler, D. (2007). Semiotics: The basics (2ed ed.). New York: Routledge.

Connotation. (2014). In The concise Oxford dictionary of linguistics (3rd. ed.) Oxford: Oxford University Press.

Denotation. (2014). In The concise Oxford dictionary of linguistics. (3rd ed.) Oxford: Oxford University Press.

Fowler, H. W. (2009). A dictionary of modern English usage. Oxford: Oxford University Press.

Gulliver's Travels. (2017). In Encyclopedia Britannica. Retrieved December 16, 2018 from https://www.britannica.com/topic/Gullivers-Travels

Hirsch, E. D. (1980). Culture and literacy. Journal of Basic Writing, 3(1), 27-47.

Kant, I. (1790). Critik der Urtheilskraft [Critique of Judgment]. J. H. Bernard (Trans.). (1951). New York: Hafner Publishing.

Morreall, J. (1987). The philosophy of laughter and humor. Albany: State University of New York.

Murphy, M. L., \& Koskela, A. (2010). Key terms in semantics. London: Continuum International Publishing Group.

Nanotechnology. (2005). In Encyclopedia Britannica. Retrieved December 16, 2018 from https://www.britannica.com/technology/nanotechnology

Palmer, F. R. (1981). Semantics: An advanced resource book for students. London: Routledge. 
Personification. (1998). In Encyclopedia Britannica. Retrieved December 16, 2018 from https://www.britannica.com/art/personification

Pun. (2013). In Encyclopedia Britannica. Retrieved December 16, 2018 from http://www.britannica.com/EBchecked/topic/483401/pun

Raskin, V. (1985). Semantic mechanisms of humour. Dordrecht: D. Reidel Publishing Company.

Richards, I. A. (1936). The Philosophy of rhetoric. London: Oxford University Press.

Ross, A. (1998). The language of humour. London: Routledge.

Selim, T. (2019, July 23). 67 years ago: Egypt overthrows British colonial rule. Scoop Empire. Retrieved January 17, 2020 from https://bit.ly/38lfqJv

Simile. (1998). In Encyclopedia Britannica. Retrieved December 16, 2018 from https://www.britannica.com/art/simile

Simpson, P. (1997). Language through literature. London: Routledge.

The World Economic Forum. (n.d.). Retrieved on May 13, 2020 from http://bit.ly/3hOZimF

Toolan, M. (2009). Narrative progression in the short story: A corpus stylistic approach. Amsterdam: John Benjamins.

Tsakona, V. (2018). Intertextuality and cultural literacy in contemporary political jokes. In A. Sover (Ed.), The languages of humor: Verbal, visual, and physical humor (pp. 86-104). London: Bloomsbury Academic.

Wordplay. (n.d.). Literary terms. Retrieved May 13, 2020 from https://literaryterms.net/wordplay/

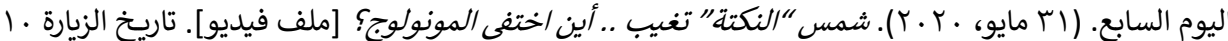

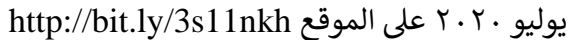

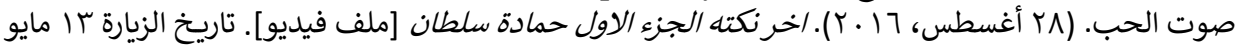

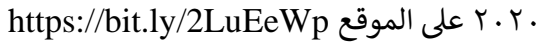

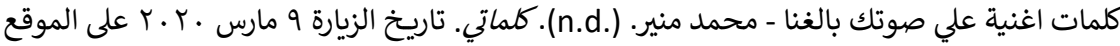

$$
\begin{aligned}
& \text { http://bit.ly/2Xf2zSL } \\
& \text { كلمات اغنية 'كنت فين' عبد الحليم حافظ. (n.d.). اكسبريدو. تاريخ الزيارة } 9 \text { مارس • ·. . على الموقع } \\
& \text { http://bit.ly/38iAO22 }
\end{aligned}
$$

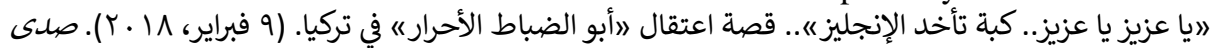

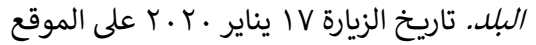

Appendix

I. Sources of the English data are alphabetically arranged as follows:

Arse Raptor. (2009, August 30). Russell Howard - live at the Apollo part 1 [Video file]. Retrieved September 15, 2017 from https://bit.ly/35gnwBq

Arse Raptor. (2010, December 10). Greg Davies - live at the Apollo [Video file]. Retrieved September 15, 2017 from https://bit.ly/35gnzx6

Arse Raptor. (2010, December 30). Steven K Amos - live at the Apollo part 1 [Video file]. Retrieved September 15, 2017 from https://bit.ly/3nncwrW

Arse Raptor. (2013, December 21). Adam Hills live at the Apollo [Video file] Retrieved September 15, 2017 from https://bit.ly/35hjJ6I

Last Week Tonight. (2014, June 1). Net neutrality: Last week tonight with John Oliver (HBO) [Video file]. Retrieved September 15, 2017 from https://bit.ly/3964UoF

Last Week Tonight. (2014, October 26). Sugar: Last week tonight with John Oliver $(H B O)$ [Video file]. Retrieved February 6, 2018 from https://bit.ly/3bgxKWk 
Last Week Tonight. (2015, February 15). Tobacco: Last week tonight with John Oliver (HBO) [Video file]. Retrieved February 6, 2018 from https://bit.ly/3hQclVd

Last Week Tonight. (2015, July 19). Food waste: Last week tonight with John Oliver (HBO) [Video file]. Retrieved February 6, 2018 from https://bit.ly/38lzNGM

Last Week Tonight. (2016, May 8). Scientific studies: Last week tonight with John Oliver (HBO) [Video file]. Retrieved February 6, 2018 from https://bit.ly/3pUaxNB

Team Coco. (2019, December 13). Martha Kelly wants to be a motivational speaker “late night with Conan O'Brien” [Video file]. Retrieved July 10, 2020 from https://bit.ly/3olqpIt

The Daily Show. (2000, February 1). Headlines - Swiss Miss [Video file].

Retrieved September 15, 2017 from https://on.cc.com/3bf8uzr

II. Sources of the Arabic data are alphabetically arranged as follows:

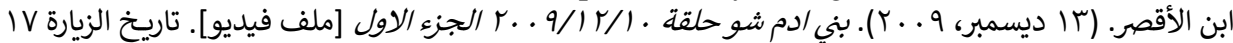

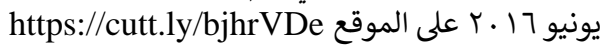

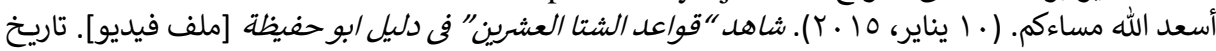

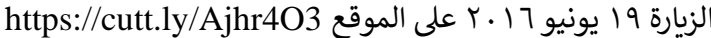

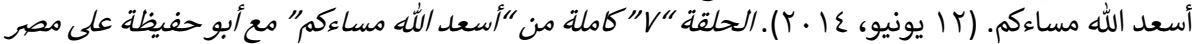

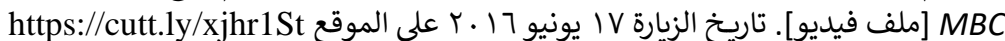

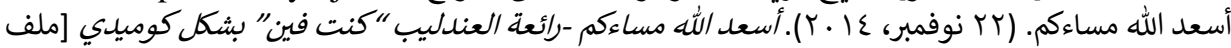

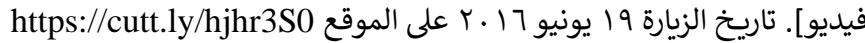

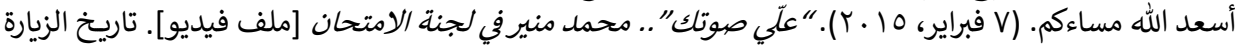

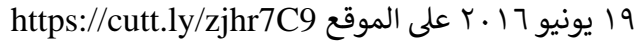

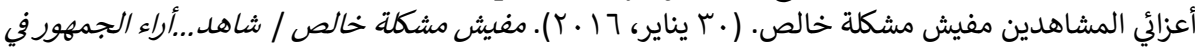

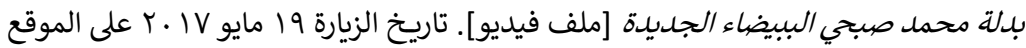
https://cutt.ly/Rjhr6k9

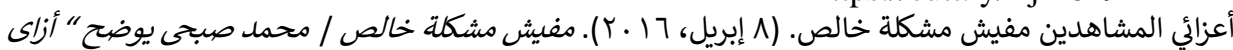

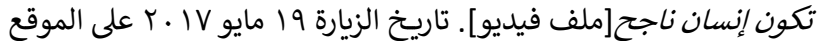

https://cutt.ly/qjhtwvG

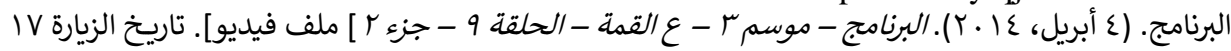

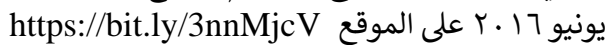

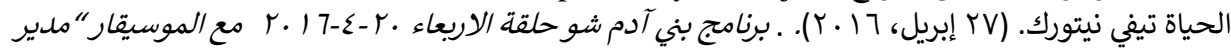

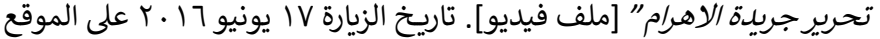
https://cutt.ly/GjhrLya

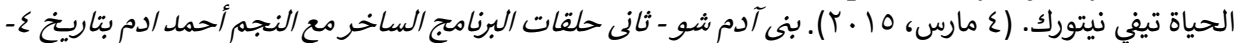

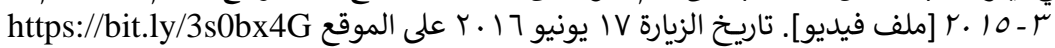

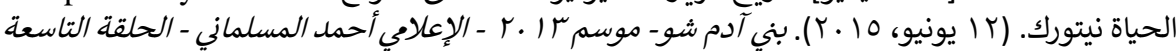

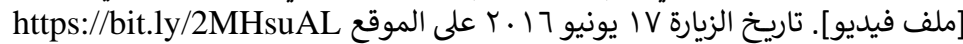

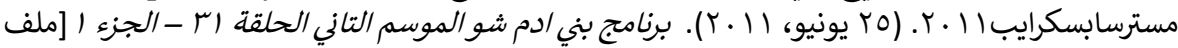

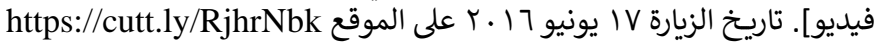

